\title{
Zoned phosphosiderite-metavariscite crystals from Eduardo Mine, Conselheiro Pena, Minas Gerais, Brazil
}

\author{
Cristais zonados de fosfossiderita-metavariscita da
} Mina do Eduardo, Conselheiro Pena, Minas Gerais, Brazil

\author{
Ingrid Souto Maia Lamoso ${ }^{1}$, Daniel Atencio ${ }^{1}$ \\ ${ }^{1}$ Instituto de Geociências, Universidade de São Paulo - USP, Rua do Lago, 562, CEP 05508-080 \\ São Paulo, SP, BR (ingrid.lamoso@usp.br; datencio@usp.br)
}

Received on February 2 $2^{\text {nd }}, 2017$; accepted on July $31^{\text {th }}, 2017$

\begin{abstract}
Zoned phosphosiderite-metavariscite crystals are recorded for the first time, in a phosphate-rich granitic pegmatite, at the Eduardo mine, Conselheiro Pena, Minas Gerais, Brazil. Metavariscite is described for the first time in Brazil. Phosphosiderite and metavariscite occur as small friable, globular agglomerates, up to $2 \mathrm{~mm}$, with purple to lilac color, in miarolitic cavities up to $1 \mathrm{~cm}$ in the pegmatite. Phosphosiderite, ideally $\mathrm{Fe}^{3+}\left(\mathrm{PO}_{4}\right) \cdot 2 \mathrm{H}_{2} \mathrm{O}$, and metavariscite, ideally $\mathrm{Al}\left(\mathrm{PO}_{4}\right) \cdot 2 \mathrm{H}_{2} \mathrm{O}$, are isostructural. Empirical formulae from $\mathrm{EDS}$ analysis $\left(\mathrm{H}_{2} \mathrm{O}\right.$ by difference) are, respectively, $\left(\mathrm{Fe}^{3+}{ }_{0.65} \mathrm{Al}_{0.24}\right)_{\Sigma 0.89}$ $\left[\mathrm{PO}_{3.67}(\mathrm{OH})_{0.33}\right] \cdot 0.96 \mathrm{H}_{2} \mathrm{O}$ and $\left(\mathrm{Al}_{0.61} \mathrm{Fe}^{3+}{ }_{0.23}\right)_{\Sigma 0.84}\left[\mathrm{PO}_{3.52}(\mathrm{OH})_{0.48}\right] .0 .97 \mathrm{H}_{2} \mathrm{O}$. The differences between ideal and empirical formulae are attributed to the instability of the crystals under the electron beams. Only the peaks for phosphosiderite were observed in the X-ray powder diffraction pattern due to the small proportion of metavariscite in the mixture. Unit cell parameters calculated for phosphosiderite are: $a$ 5.368(7), $b$ 9.778(10), c 8.710(9) $\AA, \beta$ 90.9(1) $)^{\circ}, V 457.1(9) \AA^{3}$.
\end{abstract}

Keywords: Phosphosiderite; Metavariscite; Conselheiro Pena; Minas Gerais; Zoned Crystals.

\section{Resumo}

Cristais zonados de fosfossiderita-metavariscita são registrados pela primeira vez, em um pegmatito granítico rico em fosfato, na Mina do Eduardo, Conselheiro Pena, Minas Gerais, Brasil. Metavariscita é descrita pela primeira vez no Brasil. Fosfossiderita e metavariscita ocorrem como aglomerados globulares pequenos e friáveis, de até $2 \mathrm{~mm}$, com cor púrpura a lilás, em cavidades miarolíticas de até $1 \mathrm{~cm}$ no pegmatito. Fosfossiderita, idealmente $\mathrm{Fe}^{3+}\left(\mathrm{PO}_{4}\right) \cdot 2 \mathrm{H}_{2} \mathrm{O}$, e metavariscita, idealmente $\mathrm{Al}\left(\mathrm{PO}_{4}\right) \cdot 2 \mathrm{H}_{2} \mathrm{O}$, são isoestruturais. Fórmulas empíricas a partir de análises por EDS ( $\mathrm{H}_{2} \mathrm{O}$ por diferença) são, respectivamente, $\left(\mathrm{Fe}^{3+}{ }_{0,65} \mathrm{Al}_{0,24}\right)_{\Sigma 0,89}\left[\mathrm{PO}_{3,67}(\mathrm{OH})_{0,33}\right] .0,96 \mathrm{H}_{2} \mathrm{O}$ e $\left(\mathrm{Al}_{0,61} \mathrm{Fe}^{3+}{ }_{0,23}\right)_{\Sigma 0,84}\left[\mathrm{PO}_{3,52}(\mathrm{OH})_{0,48}\right] \cdot 0,97 \mathrm{H}_{2} \mathrm{O}$. As diferenças entre as fórmulas ideais e empíricas são atribuídas à instabilidade dos cristais sob os feixes eletrônicos. Apenas os picos da fosfossiderita foram observados nos difratogramas de raios $\mathrm{X}$ devido à pequena proporção de metavariscita na mistura. Parâmetros de cela unitária calculados para fosfossiderita são: $a$ 5,368(7), $b$ 9,778(10), c 8,710(9) $\AA, \beta$ 90,9(1) ${ }^{\circ}, V 457,1(9) \AA^{3}$.

Palavras-chave: Fosfossiderita; Metavariscita; Conselheiro Pena; Minas Gerais; Cristais Zonados. 


\section{INTRODUCTION}

Phosphosiderite is ideally $\mathrm{Fe}^{3+}\left(\mathrm{PO}_{4}\right) \cdot 2 \mathrm{H}_{2} \mathrm{O}$, and metavariscite, ideally $\mathrm{Al}\left(\mathrm{PO}_{4}\right) \cdot 2 \mathrm{H}_{2} \mathrm{O}$. They are monoclinic, isostructural, and belong to the $P 2_{1} / n$ space group (Borensztajn, 1966). This is the first time that zoned crystals of these two minerals are recorded. In addition, this is the first time metavariscite is registered in Brazil.

\section{GEOLOGICAL SETTING}

The basic geological information about Eduardo Mine was summarized by Scholz et al. (2014). This mine ("Lavra do Eduardo", in Portuguese), near Boa Vista creek, Conselheiro Pena municipality, Minas Gerais, Brazil

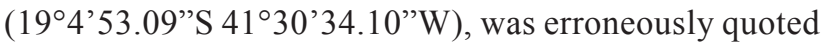
as Boa Vista Mine, another famous mine, by Bermanec et al. (2011). It is located in Conselheiro Pena Pegmatite District (Figure 1), one of the subdivisions of the Eastern Brazilian Pegmatite province, that encompasses an area of about $150,000 \mathrm{~km}^{2}$, extending from Bahia to Rio de Janeiro states (Pedrosa-Soares et al., 2011). Around 90\% of the province is situated in the eastern part of the state of Minas Gerais.

The Conselheiro Pena Pegmatite District, inserted in the central domain of Araçuaí Mobile Belt (Almeida, 1977), covers an area of about $5,000 \mathrm{~km}^{2}$, in the middle part of
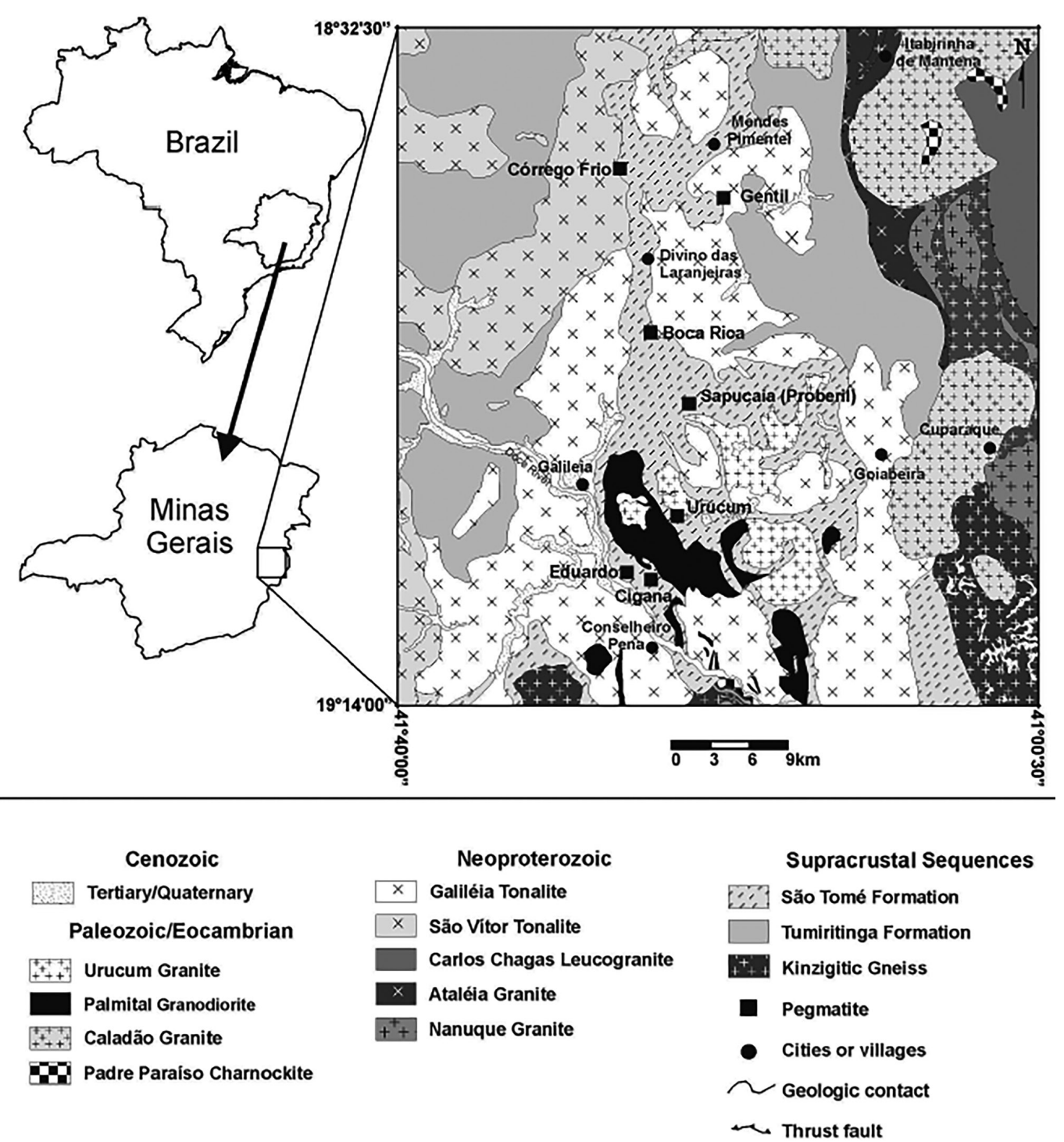

Figure 1. Geological map of the Conselheiro Pena Pegmatite district and the location of the most important phosphaterich pegmatites (after Netto et al., 1998 apud Scholz et al., 2014). 
Doce River basin, approximately $360 \mathrm{~km} \mathrm{NE}$ of the city of Belo Horizonte. It was formed during the Brasiliano orogeny (630-490 Ma) by accretion to the eastern margin of the São Francisco craton (Pedrosa-Soares et al., 2011). In this area, several suites of granitoid rocks are distinguished (e.g. Urucum and Palmital of Eocambrian to Paleozoic age, and Galileia of Neoproterozoic age), intruding schists of the Neoproterozoic São Tomé Formation (Nalini et al., 2008).

The pegmatite is heterogeneous, with well-developed mineralogical and textural zoning. It has symmetric lens shape, with the longer axis trending NW-SE and steeply dipping. Their minimum extension is around $20 \mathrm{~m}$, and the thickness is $12 \mathrm{~m}$. The pegmatite is hosted by quartzmica schist with garnet, staurolite and sillimanite of the São Tomé Formation. Tourmalinization is observed in the contact between the pegmatite and the host rock. Hydrothermal and metasomatic fluids were responsible for the albitization and development of miarolitic cavities, and a complex secondary phosphate assemblage was described by Chaves et al. (2005). The pegmatite crops out on a steep hillside, and, at the uppermost end, pinches out to less than $1 \mathrm{~m}$ in width.

Eduardo Pegmatite was mined for industrial feldspar and with minor importance gemstones and samples for the collectors market, mainly phosphates (red variscite, phosphosiderite and cyrilovite) and arsenates (scorodite and pharmacosiderite). Other minerals found in the pegmatite, including secondary species, are albite, garnets of the almandine-spessartine solid-solution series, arsenopyrite, beryl, bismuth, bütschliite, cryptomelane, löllingite, fourmarierite, frondelite-rockbridgeite solid-solution series, heterosite, hureaulite, kaolinite, leucophosphite, manganese oxides, metatorbernite, microcline, muscovite, quartz, saléeite, schorl, spodumene, strengite, triphylite, and ushkovite (Bermanec et al., 2011). Several other minerals were quoted: autunite, barbosalite, bermanite, goethite, gordonite, jahnsite-(CaMnMg), jarosite, laueite, lipscombite, meurigite-K, mitridatite, natrodufrénite, rockbridgeite, schoonerite, serrabrancaite, sulfur, symplesite, tavorite, whiteite-( $\mathrm{CaFeMg})$, and whiteite-( $\mathrm{MnFeMg})$ (http://www.mindat.org/loc-211260.html). Recently, the new mineral césarferreiraite (Scholz et. al., 2014) was described in Eduardo mine. At present, the Eduardo pegmatite is mined out.

\section{OCCURRENCE}

Phosphosiderite and metavariscite (Figure 2) occur as small friable, globular agglomerates, up to $2 \mathrm{~mm}$, with purple to lilac color, in miarolitic cavities up to $1 \mathrm{~cm}$ in the pegmatite.

\section{METHODS}

In this research there were used powder X-ray diffraction data for the phosphosiderite-metavariscite mixture, obtained with a D8 Advance DaVinci diffractometer using $\mathrm{CuK} \alpha$ radiation. The chemical compositions were obtained using a LEO440 electron microscopy equipped with Si-Li detector (EDS mode, $15 \mathrm{kV}, 1.5 \mathrm{nA}, 100 \mathrm{~s}$ counting time) in the laboratories of Institute of Geosciences, University of São Paulo. The first one allows us to identify interplanar distances of crystalline reticulum whereas the Scanning Electron Microscopy (SEM) with EDS supplies chemical data and oxide proportions. Therefore, from these data, it is possible to calculate the chemical formulae of the analyzed mineral.

\section{CHEMICAL COMPOSITION}

Chemical analyses were carried out on a zoned crystal (four analyses for phosphosiderite and five for metavariscite), and $\mathrm{H}_{2} \mathrm{O}$ was calculated by difference. Analytical data are given in Table 1. Empirical formulae (based on one $\mathrm{P}$ apfu ) are, respectively, $\left(\mathrm{Fe}^{3+}{ }_{0.65} \mathrm{Al}_{0.24}\right)_{\Sigma 0.89}$ $\left[\mathrm{PO}_{3.67}(\mathrm{OH})_{0.33}\right] .0 .96 \mathrm{H}_{2} \mathrm{O}$ and $\left(\mathrm{Al}_{0.61} \mathrm{Fe}^{3+}{ }_{0.23}\right)_{\Sigma 0.84}$ $\left[\mathrm{PO}_{3.52}(\mathrm{OH})_{0.48}\right] .0 .97 \mathrm{H}_{2} \mathrm{O}$. The differences between ideal and empirical formulae are attributed to the instability of the crystals under the electron beams. They were locally burst, as it is possible to observe in the secondary electrons image (Figure 3). Metavariscite is more unstable than phosphosiderite.

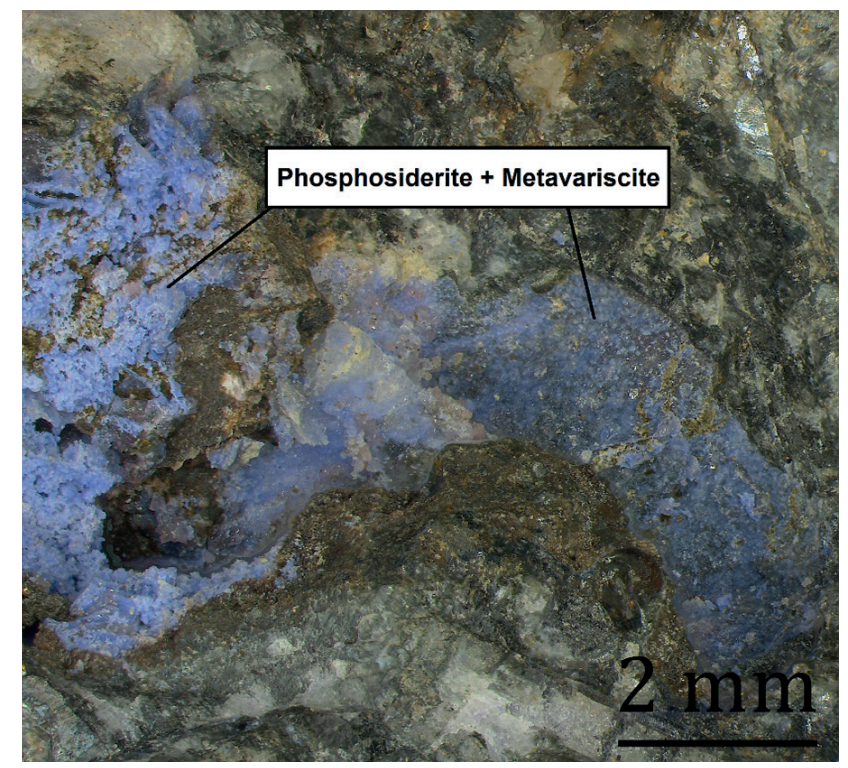

Figure 2. Minerals association of phosphosiderite and metavariscite in miarolitic cavity. 


\section{CRYSTALLOGRAPHY}

Only the peaks for phosphosiderite were observed due to the small proportion of metavariscite in the mixture
(Figure 4). The data are given in Table 2. Unit cell parameters calculated with the software CellCalc (Miura, 2003) are compared to those of phosphosiderite and metavariscite in Table 3.

Table 1. Analytical data for phosphosiderite and metavariscite.

\begin{tabular}{|c|c|c|c|c|c|}
\hline \multirow{2}{*}{ Constituent } & \multicolumn{2}{|c|}{ Phosphosiderite } & \multicolumn{2}{|c|}{ Metavariscite } & \multirow{2}{*}{ Probe standard } \\
\hline & wt $\%$ & Range & wt $\%$ & Range & \\
\hline $\mathrm{Na}_{2} \mathrm{O}$ & & & 0.05 & n.d. -0.18 & Albite \\
\hline $\mathrm{MnO}$ & & & 0.04 & n.d. -0.22 & $\mathrm{Mn}$ \\
\hline $\mathrm{CoO}$ & 0.12 & n.d. -0.46 & 0.06 & n.d. -0.28 & Co \\
\hline $\mathrm{Fe}_{2} \mathrm{O}_{3}$ & 33.25 & $30.95-38.42$ & 12.85 & $7.91-18.98$ & $\mathrm{Fe}$ \\
\hline $\mathrm{Al}_{2} \mathrm{O}_{3}^{3}$ & 7.97 & $3.72-10.41$ & 21.70 & $13.10-26.21$ & $\mathrm{Al}_{2} \mathrm{O}_{3}$ \\
\hline $\mathrm{P}_{2} \mathrm{O}_{5}$ & 45.65 & $44.52-46.93$ & 50.01 & $49.42-50.90$ & $\mathrm{GaP}^{3}$ \\
\hline $\mathrm{H}_{2}^{2} \mathrm{O}^{*}$ & (13.01) & & (15.09) & & \\
\hline Total & (100.00) & & (100.00) & - & \\
\hline
\end{tabular}

${ }^{\star}$ By difference.
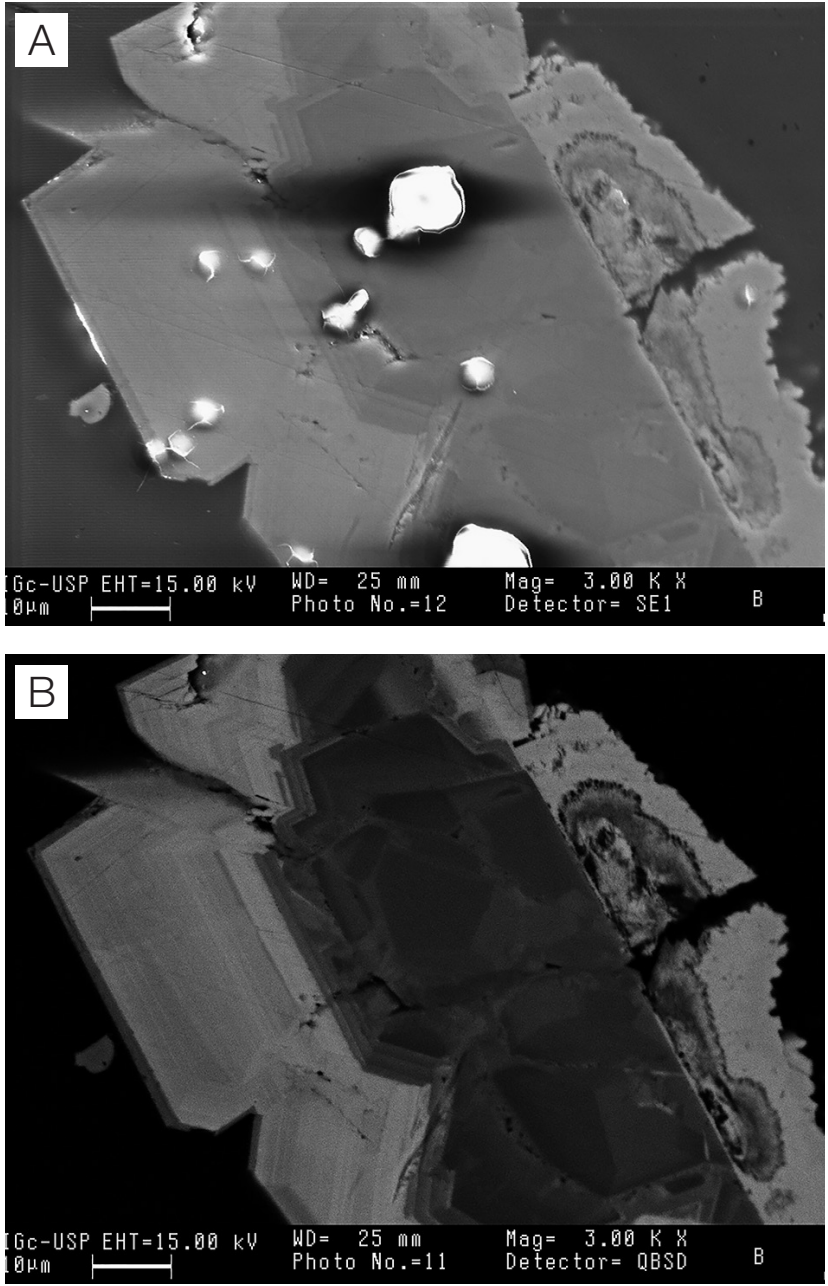

Figure 3. (A) Secondary and (B) backscattered electron images of a zoned crystal. The central part (darker) is aluminum-rich (metavariscite) and the outside part (clearer) is iron-rich (phosphosiderite).

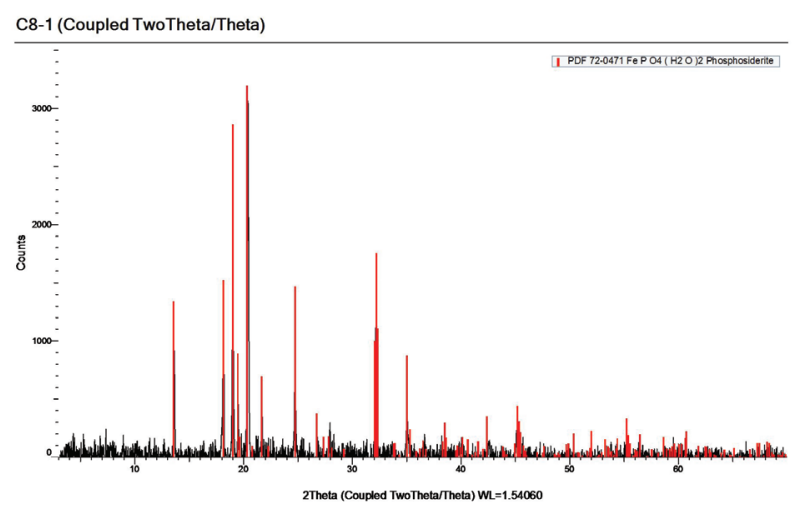

Figure 4. X-ray diffractogram for phosphosiderite.

Table 2. X-ray powder diffraction data for phosphosiderite.

\begin{tabular}{lllccc}
\hline $\mathbf{h}$ & $\mathbf{k}$ & $\mathbf{l}$ & $\mathbf{d}_{\text {calc. }}(\AA)$ & $\mathbf{d}_{\text {obs. }}(\AA)$ & $\mathbf{I}_{\text {obs. }}$ \\
\hline 0 & 1 & 1 & 6.503 & 6.479 & 16 \\
0 & 2 & 0 & 4.889 & 4.880 & 100 \\
1 & 1 & 0 & 4.705 & 4.662 & 83 \\
-1 & 0 & 1 & 4.602 & 4.548 & 12 \\
1 & 0 & 1 & 4.537 & 4.548 & 12 \\
0 & 0 & 2 & 4.354 & 4.342 & 43 \\
1 & 1 & 1 & 4.116 & 4.096 & 14 \\
1 & 2 & 0 & 3.614 & 3.596 & 19 \\
-1 & 2 & 1 & 3.351 & 3.328 & 7 \\
-1 & 1 & 2 & 3.218 & 3.197 & 7 \\
1 & 3 & 0 & 2.786 & 2.778 & 52 \\
0 & 1 & 3 & 2.783 & 2.771 & 30 \\
1 & 3 & 1 & 2.647 & 2.642 & 6 \\
-1 & 0 & 3 & 2.570 & 2.565 & 6 \\
3 & 2 & 0 & 1.680 & 1.681 & 4 \\
-2 & 1 & 4 & 1.679 & 1.681 & 4 \\
0 & 6 & 0 & 1.630 & 1.631 & 6 \\
1 & 1 & 5 & 1.626 & 1.627 & 5 \\
\hline
\end{tabular}


Table 3. Unit cell parameters for phosphosiderite from Eduardo mine compared to literature data for phosphosiderite and metavariscite.

\begin{tabular}{lccc}
\hline & $\begin{array}{c}\text { Phosphosiderite } \\
\text { from Eduardo } \\
\text { mine }\end{array}$ & Phosphosiderite & \\
\hline $\begin{array}{l}a \\
(\AA)\end{array}$ & $5.368(7)$ & $5.335(5)$ & $5.178(2)$ \\
$\begin{array}{l}b \\
(\AA)\end{array}$ & $9.778(10)$ & $9.808(12)$ & $9.514(2)$ \\
$\begin{array}{l}c \\
(\AA)\end{array}$ & $8.710(9)$ & $8.720(7)$ & $8.454(2)$ \\
$\beta\left({ }^{\circ}\right)$ & $90.9(1)$ & $90.54(5)$ & $90.35(2)$ \\
$V$ & $457.1(9)$ & 456.3 & 416.5 \\
$\left(\AA^{3}\right)$ & & & \\
\hline
\end{tabular}

${ }^{1}$ Taxer and Bartl, 2004; ${ }^{2}$ Kniep and Mootz, 1973.

\section{CONCLUSIONS}

In brief, phosphosiderite and metavariscite, identified in analysis, had not been identified in Eduardo Mine (MG) yet. It is also the first time that zoned crystals of these two minerals are described, as well as it is the first register of occurrence of metavariscite in Brazil.

\section{ACKNOWLEDGEMENTS}

We acknowledge Brazilian agency Fundação de Amparo à Pesquisa do Estado de São Paulo (FAPESP) (process 2015/05238-0) for financial support.

\section{REFERENCES}

Almeida, F. F. M. (1977). O Cráton do São Francisco. Revista Brasileira de Geociências, 7, 349-364.

Bermanec, V., Scholz, R., Markovic, F., Zigovecki-Gobac, Z., Chaves, M. L. S. C. (2011). Mineralogy of the Boa Vista pegmatite, Galileia, Minas Gerais, Brazil. 5th International Symposium on Granitic Pegmatites, Mendoza, Argentina, 14, 33-35. Mendoza: Asociación Geológica Argentina (Publicación Especial).
Borensztajn, J. (1966). Structures cristallines de la métavariscite et de la métastrengite, Bulletin de la Société Française de Minéralogie et de Cristallographie, 89, 428-438.

Chaves, M. L. S. C., Scholz, R., Atencio, D., Karfunkel, J. (2005). Assembléias e paragêneses minerais singulares nos pegmatitos da região de Galiléia (Minas Gerais). Geociências, 24, 143-161.

Kniep, R., Mootz, D. (1973). Metavariscite - A redetermination of its crystal structure. Acta Crystallographica, B29, 2292-2294.

Miura, H. (2003). CellCalc: Unit Cell Parameter Calculation Program on Windows Computer. Journal of Crystallographic Society of Japan, 45, 145-147.

Nalini Jr., H. A., Machado, R., Endo, I., Bilal, E. (2008). A importância da tectônica transcorrente no alojamento de granitos pré a sincolisionais na região do vale do médio Rio Doce: o exemplo das suítes Galiléia e Urucum. Revista Brasileira de Geociências, 38, 748-759.

Pedrosa-Soares, A. C., Campos, C. M., Noce, C. M., Silva, L. C., Novo, T. A., Roncato, J., Medeiros, S. M., Castañeda, C., Queiroga, G. N., Dantas, E., Dussin, I. A., Alkmim, F. (2011). Late Neoproterozoic-Cambrian granitic magmatism in Araçuaí orogen (Brazil), the Eastern Brazilian Pegmatite Province and related mineral resources. Geological Society Special Publication, 350, 25-51.

Scholz, R., Chukanov, N. K., Menezes Filho, L. A. D., Atencio, D., Lagoeiro, L., Belotti, F. M., Chaves, M. L. S. C., Romano, A. W., Brandão, P. R., Belakoviskiy, D. I., Pekov, I. (2014). Césarferreiraite, $\mathrm{Fe}^{2+} \mathrm{Fe}_{2}^{3+}\left(\mathrm{AsO}_{4}\right)_{2} \cdot 8 \mathrm{H}_{2} \mathrm{O}$, from Eduardo mine, Conselheiro Pena, Minas Gerais, Brazil: Second arsenate in the laueite mineral group. American Mineralogist, 99, 607-611.

Taxer, K., Bartl, H. (2004). On the dimorphy between the variscite and clinovariscite group: refined finestructural relationship of strengite and clinostrengite, $\mathrm{Fe}\left(\mathrm{PO}_{4}\right) \cdot 2 \mathrm{H}_{2} \mathrm{O}$. Crystal Research and Technology, 39, 1080-1088. 